\title{
Notice to BDA members
}

This notice accompanies the Notice to members of the Annual General Meeting (the 'AGM Notice') of the British Dental Association (the 'Association') to be held remotely on 19:30 on Tuesday 17 November 2020. As you will see from the resolutions set out in the AGM Notice, the Association is seeking its members' consent to send or supply documents and information ('Documents and Information') in electronic form via a website, as well as amending the articles of association to permit such forms of communication.

Increased use of electronic communications will deliver significant savings to the Association in terms of administration, printing and postage costs, as well as speeding up the provision of information to shareholders. The reduced use of paper will also have environmental benefits.

Under the provisions of the Companies Act 2006, we are also required to ask you individually to confirm your agreement to the Association sending or supplying the Documents and Information to you as a member of the Association via www.bda.org (the 'Website').

Assuming that the resolution to amend the Articles to permit website communications (as set out in the AGM Notice) is passed by members on 17 November 2020, if we do not receive a response from you within 28 days of the date of this notice, then you will be taken to have agreed (under paragraph 10 of Schedule 5 to the Companies Act 2006) that the Association may send or supply the
Documents and Information to you via the Website. If you do not wish to receive Documents and Information via the Website, please inform us as soon as possible (and in any event within 28 days of the date of this notice) by sending a letter addressed to the British Dental Association, 64 Wimpole Street, London W1G 8YS (marked for the attention of Stephen Skelton).

We will notify you when the Documents and Information are available to access on the Website and we will provide you with:

- The address of the Website;

- The place on the Website where the Documents and Information may be accessed; and

- Details of how to access the Documents and Information.

Please note that there may be particular circumstances in which the Association needs to send Documents or Information to you in hard copy rather than by the Website, in which case the Association reserves the right to do so.

Yours faithfully,

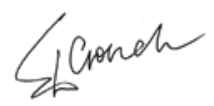

\section{Eddie Crouch}

Chair, Principal Executive Committee

British Dental Association

\section{Little progress made in 'War on Sugar'}

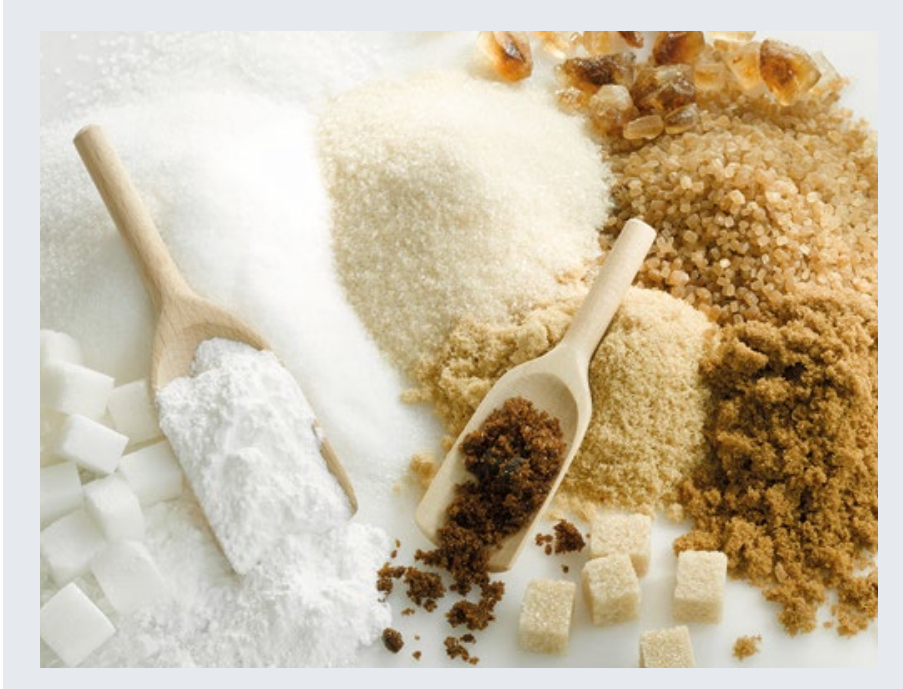

The British Dental Association (BDA) has urged ministers to turn the page on voluntary action with the food industry, as a new report from Public Health England ${ }^{1}$ indicates minimal progress to reduce sugar levels in food, with many food categories showing 'little or no reduction'.

Data from the government's flagship sugar reduction programme show the food industry has cut barely $3 \%$ of sugar from products bought in shops and supermarkets over the last four years.

Dentists have pointed to the success of mandatory action through the sugar levy, which has seen a $44 \%$ fall in the sugar levels in soft drinks since 2015, with many companies taking out sugar to avoid exposure to the tax.

Tooth decay remains the number one reason for hospital admissions among young children, and oral health inequalities are expected to widen further, driven by unprecedented access problems, the suspension of public health programmes, and sugarladen lockdown diets.

BDA Chair Eddie Crouch said: 'Britain is losing the war on sugar because ministers remain unwilling to really put up a fight. Voluntary action from industry on reformulation is making next to no headway. We need a real sense of urgency, wedded to mandatory targets.

'COVID needs to focus minds on the need for sustained action on preventable diseases like tooth decay and obesity. Hard-won gains will only slip into reverse as lockdown diets take their toll.'

\section{Reference}

1. Public Health England. Sugar reduction. Report on progress between 2015 and 2019. October 2020. Available at: https://assets.publishing.service.gov.uk/government/ uploads/system/uploads/attachment_data/file/925027/SugarReportY3.pdf (accessed October 2020). 